\title{
Concept Paper \\ Changed for the Better: The Modifiable Maltreatment Factors Framework
}

\author{
Megan Feely
}

check for

updates

Citation: Feely, M. Changed for the Better: The Modifiable Maltreatment Factors Framework. Societies 2022, 12, 21. https://doi.org/10.3390/ soc12010021

Academic Editor: Ian Kelvin Hyslop

Received: 23 November 2021

Accepted: 2 February 2022

Published: 9 February 2022

Publisher's Note: MDPI stays neutral with regard to jurisdictional claims in published maps and institutional affiliations.

Copyright: (C) 2022 by the author. Licensee MDPI, Basel, Switzerland. This article is an open access article distributed under the terms and conditions of the Creative Commons Attribution (CC BY) license (https:// creativecommons.org/licenses/by/ $4.0 /)$
School of Social Work, University of Connecticut, Hartford, CT 06103, USA; megan.feely@uconn.edu

\begin{abstract}
Rates of child maltreatment in the U.S. have been relatively stagnant since the 1990s. This lack of progress suggests that prevention efforts, which have primarily focused on individual behaviors, have been unsuccessful. Building on existing research, this conceptual paper identifies the need to refocus prevention efforts on changeable and causal risk factors. The Modifiable Maltreatment Factors (MMF), a new framework to classify risk factors for maltreatment, is introduced. Use of the MMF in social work education and child protective services work could increase the understanding of macro factors in child maltreatment and the possibilities of policy change and community organizing in maltreatment prevention.
\end{abstract}

Keywords: child maltreatment; child maltreatment prevention; child abuse; child neglect

\section{Introduction}

In the United States, child protective systems (CPS) are each state's governmental response to the need for children to be protected from abuse and neglect (referred to collectively as child maltreatment). CPS usually engages with individual families after there has been an official report of abuse or neglect; thus, the system acts only at the point of secondary or tertiary prevention. Although a CPS is the agency most associated with child maltreatment, most CPSs do not have the funding or authority to plan for the general welfare of children or support primary maltreatment prevention efforts. While some prevention efforts are conducted by public health agencies, the societal responsibility of primary prevention of child maltreatment is diffuse among governmental and private agencies.

This dispersed responsibility for children's welfare has resulted in limited success, as overall rates of child maltreatment have remained relatively constant [1]. Neglect complaints comprise $60 \%$ of all maltreatment reports, and these numbers have remained stagnant for the last 20 years [2]. In the same period, physical and sexual abuse rates have dropped, presumably because of efforts to address root causes. However, these forms of child maltreatment are less common overall than neglect.

All signs point to an urgent need for a re-examination of the causes of neglect in order to substantially reduce the incidence of child maltreatment. Because many of these factors lie outside the range of CPS, we must expand our scope. As in the case of physical and sexual abuse, refocusing research and practice efforts to build on the extant knowledge of the causes of neglect may reveal new effective avenues of prevention and yield reductions in the incidence of child neglect.

To be successful, prevention efforts should focus on the intersection of causal and modifiable factors for maltreatment. However, much of contemporary CPS practice has concentrated on assessing risk factors for future maltreatment. Many of these factors are not modifiable, such as a parent's own history of abuse, and therefore, not appropriate for intervention. Furthermore, most of the risk factor research is focused on the risk of the individual child, parent, or family. Macro factors that influence risk are often ignored [3,4].

The Modifiable Maltreatment Factors (MMF) framework is a pragmatic approach that addresses this gap in the research. This new framework focuses on modifiable factors, 
contextualizes problems that may be more effectively addressed through policy solutions or organizing efforts, and organizes the risk factors of child maltreatment across the levels of the ecological model. Through this lens, risk factors for child neglect can be prevented, rather than merely assessed.

\section{Social Work and Child Protection}

Over the last century, social work and child protection practice have migrated from a focus on community factors and structural issues to privileging the individual in the assessment and addressing of problems. In their seminal book, Specht and Courtney [5] describe the objective of social work as "to help people make use of social resources to solve their problems" with a focus on "social problems, which concern the community, rather than personality problems of individuals" [6]. Since the 1920s, psychiatry and psychodynamic theory have developed explanations and treatments for individuals' problems. The dominant focus on the individual accelerated again starting in the 1980s as neoliberal policies sought to transfer social responsibilities to individuals by cutting social programs [7]. These two trends have contributed to social work training and practice that decontextualizes the problems of the individual separately from the societal context in which people live [7].

Consequently, community organizing, policy change, and other forms of macro social work have become marginalized in education and practice. Although the Council on Social Work Education (CSWE) in the United States identifies three levels of social work practicenamely, micro-, mezzo-, and macro-levels [8]-these levels are not treated with equal focus in the field. Micro- and mezzo-level practices work with individuals and groups to "help them cope with their situations" [8]. Macro-level practice aims to " ... lead and establish social change on a large scale through organizing, policy change, and administration" [8]. The majority of social work education, training, and practice focuses on the micro levels, particularly clinical practice.

For years, this tension between individual and societal sources of problems has been reflected in the study of child maltreatment. In 1968, The Battered Child presented an image of abusive parents as deviant or pathological [9]. This was followed by the passage of the Child Abuse Prevention and Treatment Act (CAPTA) in 1974, the first federal legislation on child maltreatment. CAPTA, as the name suggests, is primarily focused on individual causes of, and interventions for abuse rather than structural or policy solutions to neglect.

Yet in the Congressional testimony, it is clear that legislators and the experts they interviewed understood that neglect in particular was influenced by financial hardship $[10,11]$. The pull of neoliberal, individualistic policies, then and now, is strong. The political decision to frame child maltreatment as a result of individual pathology set in motion a system focused on protecting children from parents who had individual-level problems. Consequently, the majority of the child welfare system's 21 billion dollars a year is spent on foster care or psychosocial interventions [12].

These mutually reinforcing trends have had significant ramifications in the way child welfare work is taught by schools of social work and practiced in the field. Child welfare has become synonymous with the formal system of child protective services and the individuallevel work within state-run or contract agencies. These agencies are charged with child protection, interpreted as secondary and tertiary prevention or treatment, such as therapy for children and parents, parent training courses, or referrals to other types of support services. This has led to a focus within CPS on individual-level risk factors and individual or family-focused interventions to address problems that are apparent and measureable at the individual level, such as mental health, substance misuse, and parent behaviors [13].

What has been lost is the role of policies in creating the worlds of individuals. Consequently, scholarship and policy have not focused on possibilities for prevention of child maltreatment through community change and macro factors. 


\section{The Need for Contextualized Child Welfare Training}

In order to prevent neglect, child welfare prevention efforts should recognize how an individual's experience is contextualized within their environment. Social workers should question not only how the environment may influence individual actions but what about the environment can and should be changed [7]. Social work training incorporates different versions of the person-in-environment, or ecological model, which situates individuals within multiple layers of the environment that may influence them [14]. Belsky [15] proposed the initial ecological model of child maltreatment, and this model is still referenced in studies of maltreatment risk, for example Mulder and colleagues [16]. However, his ecological model presents ontogenic (the parent's history, behavior, and experiences that are relevant in the family dynamic) and individual family characteristics as the most relevant risk factors. The exosystem, which includes formal and informal social structures such as the neighborhood, and the macro-system, the values and cultural beliefs, receive far less attention. Within Belsky's model, the exosystem influence is still filtered through individual characteristics, as in the case of certain individuals being more susceptible to unemployment, rather than considering the external factors. While research has advanced in the last 40 years and our understanding of the exo- and macro-system factors have expanded dramatically, the perception that child maltreatment is essentially an individual act and that the ontogenic and individual factors are still the most influential factors has persisted, for example in an article by Stith and colleagues [17].

A significant limitation of the ecological model for social work practice is its focus on identifying and understanding the interactions between the factors influencing the individual rather than on understanding how to tackle the factors that are influencing maltreatment at different levels. Social workers and other child welfare workers could be better prepared to work with families and contextualize the families' situations if they were taught a more specific and applied contextual framework for maltreatment.

Structural risks, i.e., risks related to economic situations that derive from longstanding implicit and systemic bias and racism, often manifest and are measured or assessed at the level of the individual [3]. Teaching about child maltreatment with the essential background knowledge of the exo- and macro-system factors that directly influence maltreatment risk would prepare social workers to identify what in the family's environment could be changed. Specifically, the point at which risk originates and where it may be most effectively addressed is often a different level than where the risk is typically observed [3].

Most importantly, contextualizing issues elucidates how many of the exo- and macrosystem problems are not intractable situations. For example, in child welfare practice, stable housing is observed at the individual level and usually attributed to individual capacity and decisions. However, lack of stable housing is the result of policy decisions to withhold this resource. The access to, and availability of stable housing is better understood through complex economic and policy-level decisions, such as the under-funding of the federal Housing Choice Voucher Program and the role of structural racism in what programs are funded.

Consequently, increasing access to housing is more effectively addressed at the policy level. Similarly, the effects of contaminated drinking water are apparent when individuals and families become ill. However, the majority of that risk does not originate in individual homes; teaching everyone to boil their water is not the most efficient solution.

Training social workers to identify problems that originate beyond individuals, and naming those problems as changeable, should be central to social work training in child welfare.

\section{Modifiable Factors}

\section{The MMF Framework}

The MMF framework is a novel theoretical framework of modifiable and nonmodifiable risk factors. All social work requires a triage of what factors to prioritize; the MMF framework allows practitioners to focus efforts on factors where change is most possible, and to expand our conception of what factors are modifiable. 
This pragmatic approach focuses maltreatment prevention efforts on modifiable factors at different levels and allows social workers to both contextualize individual and family issues within a macro context and identify risk factors that are fixed.

Child maltreatment prevention efforts lack a clear and cohesive definition of modifiable factors and the recent use of the term in the literature has been inconsistent or undefined $[6,18]$. Classifying risk factors as modifiable or nonmodifiable is widely used in medical research and practice [19]. Based on a definition from medical research [19], the following definition of modifiable factors in child maltreatment prevention is proposed:

- Factors that are likely to be related or contributing to the maltreatment;

- May be or are likely to be causal (exploring or establishing the causal nature of all risk factors was beyond the scope of this article);

- Were present before the incident;

- Can be changed;

- If changed, reduce the risk of future maltreatment.

The MMF divides modifiable factors into service-modifiable, policy-responsive, and organizing-modifiable factors.

Service-modifiable factors can be improved by time-limited services or programs.

Policy-responsive factors can be changed but need to be widely available and sustained beyond the time of a typical program.

Organizing-modifiable factors are exosystem, or community factors, that can be transformed through community organizing.

Currently, most maltreatment prevention programs focus on service-modifiable factors. Precision in these definitions allows us to see greater possibilities in what factors are modifiable; examples of each factor categorization are given below. Table 1 identifies the categories in the MMF and provides examples of risk factors and responses.

Table 1. MMF Categories and Examples.

\begin{tabular}{|c|c|c|c|c|c|}
\hline $\begin{array}{c}\text { MMF } \\
\text { Category }\end{array}$ & Definition & $\begin{array}{c}\text { Level Where Risk Is } \\
\text { Measured }\end{array}$ & $\begin{array}{l}\text { Level to } \\
\text { Address for } \\
\text { Prevention }\end{array}$ & $\begin{array}{c}\text { Example Risk } \\
\text { Factors }\end{array}$ & Modification \\
\hline $\begin{array}{l}\text { Service- } \\
\text { modifiable }\end{array}$ & $\begin{array}{l}\text { Factors that can be } \\
\text { improved with } \\
\text { time-limited } \\
\text { services or } \\
\text { programs. }\end{array}$ & $\begin{array}{l}\text { Individual/ } \\
\text { family }\end{array}$ & $\begin{array}{l}\text { Individual/ } \\
\text { family }\end{array}$ & $\begin{array}{c}\text { Parenting behavior, } \\
\text { particularly use of } \\
\text { corporal } \\
\text { punishment [17]. } \\
\text { Use of corporal } \\
\text { punishment } \\
\text { increases the risk } \\
\text { of physical abuse. }\end{array}$ & $\begin{array}{c}\text { Healthy Families } \\
\text { America, an } \\
\text { evidence-based } \\
\text { home visiting } \\
\text { program that } \\
\text { works with parents } \\
\text { on discipline } \\
\text { practices and } \\
\text { positive } \\
\text { parent-child } \\
\text { interactions [20]. }\end{array}$ \\
\hline $\begin{array}{l}\text { Policy- } \\
\text { responsive }\end{array}$ & $\begin{array}{l}\text { Factors that can be } \\
\text { changed but need } \\
\text { to be widely } \\
\text { available and } \\
\text { sustained beyond a } \\
\text { time-limited } \\
\text { program. }\end{array}$ & Individual & Policy & $\begin{array}{l}\text { Lack of safe and } \\
\text { consistent } \\
\text { childcare [21]. } \\
\text { Many low-income } \\
\text { families cannot } \\
\text { afford childcare } \\
\text { leaving them to } \\
\text { use informal and } \\
\text { often inconsistent } \\
\text { childcare. }\end{array}$ & $\begin{array}{l}\text { Widely available } \\
\text { childcare subsidies } \\
\text { so that parents can } \\
\text { access safe and } \\
\text { consistent } \\
\text { childcare [22]. }\end{array}$ \\
\hline
\end{tabular}


Table 1. Cont.

\begin{tabular}{|c|c|c|c|c|c|}
\hline $\begin{array}{c}\text { MMF } \\
\text { Category }\end{array}$ & Definition & $\begin{array}{c}\text { Level Where Risk Is } \\
\text { Measured }\end{array}$ & $\begin{array}{l}\text { Level to } \\
\text { Address for } \\
\text { Prevention }\end{array}$ & $\begin{array}{c}\text { Example Risk } \\
\text { Factors }\end{array}$ & Modification \\
\hline $\begin{array}{l}\text { Organizing- } \\
\text { modifiable }\end{array}$ & $\begin{array}{l}\text { Mezzo- or } \\
\text { community-level } \\
\text { that can be } \\
\text { transformed } \\
\text { through } \\
\text { community } \\
\text { organizing. }\end{array}$ & $\begin{array}{l}\text { Individual/ } \\
\text { Community }\end{array}$ & Community & $\begin{array}{l}\text { Neighborhood } \\
\text { disorganization, } \\
\text { i.e., neighborhoods } \\
\text { where it is difficult } \\
\text { for residents to } \\
\text { collectively } \\
\text { address problems } \\
\text { that affect the } \\
\text { community [23]. }\end{array}$ & $\begin{array}{l}\text { Community } \\
\text { organizing with a } \\
\text { focus on families } \\
\text { can support } \\
\text { residents in } \\
\text { developing and } \\
\text { executing a plan } \\
\text { that addresses } \\
\text { their community's } \\
\text { specific needs and } \\
\text { builds community } \\
\text { capacity for future } \\
\text { issues. }\end{array}$ \\
\hline Nonmodifiable & $\begin{array}{l}\text { Factors related to } \\
\text { and/or } \\
\text { contributing to the } \\
\text { maltreatment, and } \\
\text { cannot be changed, } \\
\text { could not have } \\
\text { been prevented } \\
\text { with current } \\
\text { efforts. }\end{array}$ & $\begin{array}{l}\text { Individual and } \\
\text { community }\end{array}$ & NA & $\begin{array}{l}\text { Late or no prenatal } \\
\text { care [24]. This may } \\
\text { be a proxy for } \\
\text { poverty and/or it } \\
\text { may be associated } \\
\text { with a medically } \\
\text { fragile infant. It is } \\
\text { more difficult to } \\
\text { care for a child } \\
\text { who needs a higher } \\
\text { level of care. }\end{array}$ & $\mathrm{NA}$ \\
\hline
\end{tabular}

\section{Service-Modifiable Factors}

Service modifiable factors are ones that can be influenced and improved by services or programs, with programs defined as a time-limited set of services to achieve a specific goal for a specific population or group of people [25]. These factors are often identified under the blanket category of maltreatment risks; classifying them into the framework clarifies that they are a modifiable factor. They are not fixed circumstances, and should be separated from non-modifiable factors. Service-modifiable factors are identified at the individual child, individual parent, parent-child interaction, and family levels.

For example, children who exhibit behavioral problems are at an increased risk of maltreatment $[16,17]$. There are several evidence-based programs that focus on changing parent behavior with the goal of improving child behavior. Parent Child Interaction Therapy (PCIT) is an example of an evidence-based program that improves child behavior. PCIT is completed in an average of 12-14 sessions and works with parents and children to increase their positive interactions and for parents to learn consistent and non-corporal disciplinary approaches [26].

The services rarely focus exclusively on one type of risk and many of the evidencebased programs that address these modifiable factors may be used to intervene on one or more of these issues. For example, Pathways Triple P may address parenting behaviors, parental stress, and child behavioral problems [27], all of which are child maltreatment risks $[17,28]$. Assessment of these factors and interventions to address them are, and should remain, an important part of child welfare practice.

\section{Policy-Responsive Factors}

Many of the factors that are associated with maltreatment risk are modifiable but are not amenable to the typical and time-limited services that families are referred to by CPS. Policy-responsive factors are associated with maltreatment risk, and can be changed, but need to be widely available and sustained beyond a time-limited program. Many of 
the policy-responsive factors are variations of poverty, financial hardship, or economic instability, such as family poverty or low socio-economic status $[16,17,28,29]$. These issues are apparent and measured at the individual level but are shaped by the exo- and macro-systems.

For example, family poverty is identified at the individual level. While modifiable, it is more effectively addressed through policy solutions that increase the amount of money available to low-income families than through short-term individual interventions. Increasing the refundable portion of the Earned Income Tax Credits increases the amount of money available to families and has been associated with lower rates of maltreatment [30]. In 2019, the average Federal EITC refund was $\$ 2476$ and was received by more than 25 million people [31]. Increasing the credit or raising the income limit are sustainable and large-scale approaches to reducing family poverty.

These modifiable factors and the policy solutions that may address them tend to be outside the scope of traditional CPS services and the perspective of CPS, yet CPS is often held responsible for addressing the downstream impact of their effects on individuals [3]. Policy-responsive factors may need to be widely and continuously addressed, as they negatively impact individuals in a capitalistic society, such as unemployment, inconsistent income, and unaffordable housing.

\section{Structural Risk and Systemic Racism}

Poverty and structural racism are intertwined and have been reinforced by policies. Focusing research and practice efforts on policies that increase economic support for families should reduce the racial disproportionality in the child welfare system. The structure of U.S. society has made poverty a chronic and episodic problem [32] and as a consequence of the country's structural racism, the people who are most likely to live in poverty are not randomly distributed. "Structural racism refers to the totality of ways in which societies foster racial discrimination through mutually reinforcing systems of housing, education, employment, earnings, benefits, credit, media, health care, and criminal justice" [33]. The societally encompassing system of these mutually reinforcing subsystems results in racially-determined disparity [34]. In the U.S., families and individuals who are Black, Indigenous, and People of Color (BIPOC) are far more likely to experience multiple types of economic hardship and have more barriers to establishing and sustaining financial stability than white families and individuals. Particularly for children, structural racism and poverty are intertwined; $69.5 \%$ of children who are Black will spend some time in poverty compared to only $25.9 \%$ of children who are white [32,35].

Given the evidence supporting a causal relationship between economic hardship and maltreatment, it follows that structural racism is a significant driver of the overrepresentation of children and families who are BIPOC in the child welfare system, in addition to issues of bias that results in families of color being more likely to be reported to CPS than white families [3]. Expansion of affordable housing, nutritional support, childcare, basic income, and other family-support policies would positively affect a proportionally larger percentage of families who are BIPOC. Continuing to rely on individual-level approaches, such as only addressing service-modifiable factors, requires historically oppressed groups to attempt to make and maintain individual-level changes in the absence of policy-level changes. This approach perpetuates structural racism and white supremacy. Reducing the number of families who are BIPOC living with financial hardship should lead to lower disproportionality in the race and ethnicity of child welfare-involved children. These policy changes will not eliminate racial income and asset disparities or dismantle the interconnected systems of discrimination, but they would benefit many BIPOC children and families.

\section{The Exosystem and Organizing-Modifiable Factors}

In addition to the policy-responsive factors that have been identified above, there are other potentially modifiable exosystem or neighborhood-level factors such as social 
support, social cohesion, social networks, neighborhood disorganization, and collective efficacy that are associated with child maltreatment [23]. Addressing these community factors is not part of traditional individual-focused CPS services. These factors might improve with more supportive policies but they also may not be directly affected by policy changes. However, they are factors that may be addressed through one or more types of community organizing, including planning, which focuses on bringing needed services into a community; community development, where residents come together to identify their needs and how they want to solve them; and social action, where the goal is to change the structures of institutions and policies [36].

While there are valuable evidence-supported interventions that focus on community change, such as Keeping Families Together and Communities that Care [37,38], these programs are based on an individual and psychosocial understanding of child maltreatment that is addressed by evidence-based therapeutic programs, increasing social support, and other similar services. Neither approach centers power and authority for change within the community, nor do they advocate for systemic change.

Through organizing training, social workers can learn how to support communities in developing their own solutions and advocating for changes identified by community members themselves. These efforts could provide a more equitable, just, and sustainable approach to strengthening communities for families.

While community organizing is neither a policy nor a program, it is a core type of social work that may be an under-utilized approach to prevent child maltreatment. Considered from a different perspective, prevention of child maltreatment may be an under-measured positive externality of community organizing and, like policies that reduce maltreatment, should be credited as such [10].

\section{Nonmodifiable Factors}

Nonmodifiable factors are factors associated with maltreatment, present before the initial occurrence of maltreatment, which may be causal, but cannot be changed, and could not have been prevented. Research on the risks of non-modifiable factors has contributed to the ability to identify service-priority families, and to the assessment of future maltreatment risk. However, undifferentiated types of risk make the contextualization of individual factors more difficult and fail to direct social workers toward change.

An example of a nonmodifiable factor is family composition, with parents who are married or reside together being lower risk than single parents [16,17]. This finding may be used to identify priority families for services or to assess risk. However, family composition is not amenable to services, policies, or community organizing and it is not useful in identifying how to prevent maltreatment.

\section{Unclassifiable Factors}

For some risk factors, additional information is needed to classify them into the MMF. For example, White and colleagues [28] describe "child disability/developmental problem/emotional disturbance", which are distinct types of issues. For example, a developmental disability (nonmodifiable) may be associated with maltreatment as a result of the parents' lack of resources and skills to cope with the child's condition and needs (service-modifiable).

\section{The MMF and Social Work Education and Practice}

We need to teach social work students to understand the many causes and risk factors of child maltreatment. The MMF provides a framework for social work education, practice, and research to examine and contextualize these factors across the ecological levels, to separate the modifiable factors from those that are immutable, and to identify loci of change.

The MMF breaks the hold that individual factors have on the instruction of child welfare; its use would be a shift in how we conceptualize this training. Child welfare courses are usually taught from the perspective that the risk of child maltreatment is 
concentrated at the individual and ontogenic levels. This does a disservice to children and families by failing to identify greater points of change and promoting advocacy for those changes.

The model also demonstrates how all levels of social work practice with different types of skills are relevant to preventing child maltreatment. In particular, the framework guides the conceptualization of risk factors that originate, and should be addressed, at the exo- and macro-systems through social change. The model also highlights the need for macro-social workers to focus on maltreatment prevention through policy changes and community organizing.

Teaching a framework that illustrates the modifiable possibilities for change at different levels opens up new avenues for macro work. This shift may give social workers who are more interested in working with individuals or groups a better understanding of the fact that adverse conditions are neither immutable nor simply the fault of individuals; it may also give a clearer understanding of how to support and advocate for the changes their clients need.

The MMF is complementary to current prevention approaches and models. A more comprehensive overview of maltreatment prevention frameworks can be found in the literature, for example by Jones Harden and colleagues [39], but two prominent perspectives are a strategy of evidence-based programs and of applying a public health approach [39-41]. The program strategy results in an array of specific evidence-based interventions that address different risk factors for child maltreatment, such as parenting behaviors. The majority of these programs focus on individual families and may be offered to families who are not involved with CPS services [39].

The public health model is the other prominent approach that has received significant attention in the literature, for example by Herrenkohl and colleagues [40] and is exemplified by the efforts of the Centers on Disease Control to prevent child maltreatment [41]. The public health model has many components, including developing an accurate epidemiological assessment, identification of causes, development, and evaluation of interventions, and disseminating effective approaches. This model incorporates cross-system collaboration for maltreatment prevention. Like the MMF, the public health model also takes factors at a variety of levels into consideration and attempts to address root causes to prevent a primary occurrence of maltreatment.

The MMF complements these two approaches. With the program strategy, the MMF can be useful in identifying the focus of the available programs in a particular area and what risks are not addressed. The MMF is a helpful instructional framework for working within a professional setting that uses the public health model. The narrow focus on individuals and families may limit social workers' perceptions of the targets of change once they are in the field. By teaching the MMF and extending the range of child welfare practice and maltreatment prevention to the exo- and macro-systems, social workers will be more prepared to engage with the public health approach. Additionally, the public health model seems to be particularly useful in providing a structure for cross-agency collaboration for maltreatment prevention.

\section{Limitations and Challenges for the MMF in Social Work Education}

There are some limitations to the MMF for education and practice. For example, the classifications may not be mutually exclusive. Because of the complexity of the issues and their entrenchment in society, classifying some issues into only a service-modifiable or policy-responsive factor is not always possible. This is particularly challenging with chronic and episodic problems such as substance misuse [42]. However, change is possible and often needed at multiple levels. Allowing this complexity to remain in the model better reflects the realities of society.

For example, families who have had a recent incident of maltreatment and are in an acute crisis may benefit from intensive and time-limited supportive housing [43]. However, an expansion of affordable housing or an increase in housing subsidies would prevent 
many families from an initial maltreatment incident. It would also provide ongoing support for families after they have ended their CPS involvement to prevent a subsequent incident. This complex issue does not fall neatly into one classification. Nevertheless, students-and scholars-should engage with these complexities.

Another challenge to the application of the MMF is that at this time, research has not established all of the factors that are causal, or how strong the effect of specific factors is on risk. This makes it difficult to identify the most important factors for prevention efforts. However, ambiguity about the impact of specific factors is common in social work; students need to learn approaches to addressing complex problems in the absence of definitive information.

\section{Conclusions}

Preventing maltreatment, and promoting the welfare of children, is a broader goal than child protection systems can accomplish alone. Social work education should acknowledge this breadth in its approach to teaching child welfare and maltreatment prevention. In particular, there is a role for macro social workers to see some of their work, especially in communities and on family-related policies, as preventing child maltreatment and supporting families.

This paper introduces the MMF framework, which redirects the focus of maltreatment prevention from individuals to a contextualization of individual situations within modifiable, structural factors. People do not exist in isolation, and we know that improved societal conditions can improve the lives of individuals. With this framework, social workers can more effectively approach maltreatment risk factors that are modifiable and work to realize those modifications through policy and community change.

Funding: This research received no external funding.

Institutional Review Board Statement: Not applicable.

Informed Consent Statement: Not applicable.

Data Availability Statement: Not applicable.

Conflicts of Interest: The author declares no conflict of interest.

\section{References}

1. Finkelhor, D.; Saito, K.; Jones, L. Updated Trends in Child Maltreatment, Crimes against Children Research Center. 2018. Available online: http:/ / unh.edu/ccrc/pdf/Updated\%20trends\%202016.pdf (accessed on 15 January 2019).

2. U.S. Department of Health \& Human Services, Administration for Children and Families, Administration on Children, Youth and Families, Children's Bureau. Child Maltreatment. 2020. Available online: https://www.acf.hhs.gov/cb/research-datatechnology / statistics-research/child-maltreatment (accessed on 19 January 2022).

3. Feely, M.; Bosk, E.A. That Which is Essential has been Made Invisible: The Need to Bring a Structural Risk Perspective to Reduce Racial Disproportionality in Child Welfare. Race Soc. Probl. 2021, 13, 49-62. [CrossRef] [PubMed]

4. $\quad$ Lindsey, D. The Welfare of Children; Oxford University Press: Oxford, UK, 2004.

5. Specht, H.; Courtney, M.E. Unfaithful Angels: How Social Work Has Abandoned Its Mission; Simon and Schuster: New York, NY, USA, 1995.

6. Jonson-Reid, M.; Chiang, C.-J.; Kohl, P.; Drake, B.; Brown, D.; Guo, S.; Kim, H.; McBride, T. Repeat reports among cases reported for child neglect: A scoping review. Child Abus. Negl. 2019, 92, 43-65. [CrossRef] [PubMed]

7. Fisher, R.; Karger, H.J. Social Work and Community in a Private World: Getting Out in Public; Longman: Harlow, UK, 1997.

8. Council on Social Work Education (n.d.). What is Social Work? Available online: https://www.cswe.org/Students/DiscoverSocial-Work/What-is-social-work (accessed on 13 January 2022).

9. Helfer, R.E.; Kempe, C.H. The Battered Child; University of Chicago Press: Chicago, IL, USA, 1968.

10. Feely, M.; Raissian, K.M.; Schneider, W.; Bullinger, L.R. The Social Welfare Policy Landscape and Child Protective Services: Opportunities for and Barriers to Creating Systems Synergy. Ann. Am. Acad. Polit. Soc. Sci. 2020, 692, 140-161. [CrossRef]

11. Nelson, B.J. Making an Issue of Child Abuse; University of Chicago Press: Chicago, IL, USA, 1984.

12. Haskins, R. Child Welfare Financing: What Do We Fund, How, and What Could Be Improved? Ann. Am. Acad. Polit. Soc. Sci. 2020, 692, 50-67. [CrossRef]

13. Fluke, J.D.; Yuan, Y.-Y.T.; Edwards, M. Recurrence of maltreatment: An application of the National Child Abuse and Neglect Data System (NCANDS). Child Abus. Negl. 1999, 23, 633-650. [CrossRef] 
14. Bronfenbrenner, U. Ecological models of human development. In Readings on the Development of Children, 4th ed.; Gauvain, M., Cole, M., Eds.; Worth Publishers: New York, NY, USA, 2005; pp. 3-8.

15. Belsky, J. Child maltreatment: An ecological integration. Am. Psychol. 1980, 35, 320. [CrossRef] [PubMed]

16. Mulder, T.M.; Kuiper, K.C.; van der Put, C.E.; Stams, G.-J.J.; Assink, M. Risk factors for child neglect: A meta-analytic review. Child Abus. Negl. 2018, 77, 198-210. [CrossRef] [PubMed]

17. Stith, S.M.; Liu, T.; Davies, L.C.; Boykin, E.L.; Alder, M.C.; Harris, J.M.; Som, A.; McPherson, M.; Dees, J. Risk factors in child maltreatment: A meta-analytic review of the literature. Aggress. Violent Behav. 2009, 14, 13-29. [CrossRef]

18. Waid, J.; Santaularia, N.J.; Piescher, K.; La Liberte, T. A latent class analysis of modifiable risk factors associated with child maltreatment re-reporting and recurrence. Child Abus. Negl. 2021, 120, 105249. [CrossRef]

19. Siegler, J.E.; Boehme, A.K.; Kumar, A.D.; Gillette, M.A.; Albright, K.C.; Beasley, T.M.; Martin-Schild, S. Identification of Modifiable and Nonmodifiable Risk Factors for Neurologic Deterioration after Acute Ischemic Stroke. J. Stroke Cerebrovasc. Dis. 2013, 22, e207-e213. [CrossRef]

20. DuMont, K.; Mitchell-Herzfeld, S.; Greene, R.; Lee, E.; Lowenfels, A.; Rodriguez, M.; Dorabawila, V. Healthy Families New York (HFNY) randomized trial: Effects on early child abuse and neglect. Child Abus. Negl. 2008, 32, 295-315. [CrossRef] [PubMed]

21. Ha, Y.; Collins, M.E.; Martino, D. Child care burden and the risk of child maltreatment among low-income working families. Child. Youth Serv. Rev. 2015, 59, 19-27. [CrossRef]

22. Yang, M.-Y.; Maguire-Jack, K.; Showalter, K.; Kim, Y.K.; Slack, K.S. Child care subsidy and child maltreatment. Child Fam. Soc. Work 2019, 24, 547-554. [CrossRef]

23. Coulton, C.J.; Crampton, D.S.; Irwin, M.; Spilsbury, J.C.; Korbin, J.E. How neighborhoods influence child mal-treatment: A review of the literature and alternative pathways. Child Abus. Negl. 2007, 31, 1117-1142. [CrossRef]

24. Putnam-Hornstein, E.; Needell, B. Predictors of child protective service contact between birth and age five: An examination of California's 2002 birth cohort. Child. Youth Serv. Rev. 2011, 33, 1337-1344. [CrossRef]

25. Yuen, F.K.O.; Terao, K.L. Chapter 5: Grant Proposal Writing: Beginning with the End in Mind. Effective Grant Writing and Program Evaluation for Human Service Professionals; Thomson/Brooks Cole: Pacific Grove, CA, USA, 2009; pp. 99-138.

26. Chaffin, M.; Funderburk, B.; Bard, D.; Valle, L.A.; Gurwitch, R. A combined motivation and parent-child interaction therapy package reduces child welfare recidivism in a randomized dismantling field trial. J. Consult. Clin. Psychol. 2011, 79, 84. [CrossRef] [PubMed]

27. Lewis, E.M.; Feely, M.; Seay, K.D.; Fedoravicis, N.; Kohl, P.L. Child Welfare Involved Parents and Pathways Triple P: Perceptions of Program Acceptability and Appropriateness. J. Child Fam. Stud. 2016, 25, 3760-3770. [CrossRef]

28. White, O.G.; Hindley, N.; Jones, D.P. Risk factors for child maltreatment recurrence: An updated systematic review. Med. Sci. Law 2014, 55, 259-277. [CrossRef]

29. Conrad-Hiebner, A.; Byram, E. The Temporal Impact of Economic Insecurity on Child Maltreatment: A Systematic Review. Trauma Violence Abus. 2020, 21, 157-178. [CrossRef]

30. Berger, L.M.; Font, S.A.; Slack, K.S.; Waldfogel, J. Income and child maltreatment in unmarried families: Evidence from the earned income tax credit. Rev. Econ. Househ. 2017, 15, 1345-1372. [CrossRef]

31. Internal Revenue Service. Statistics for Tax Returns with the Earned Income Tax Credit (EITC). Available online: https:/ / www.eitc.irs.gov / eitc-central/statistics-for-tax-returns-with-eitc/statistics-for-tax-returns-with-the-earned-income\# Previous\%20Tax\%20Years (accessed on 13 January 2022).

32. Rank, M.R.; Yoon, H.S.; Hirschl, T.A. American poverty as a structural failing: Evidence and arguments. J. Soc. Soc. Welf. 2003, $30,3$.

33. Bailey, Z.; Krieger, N.; Agénor, M.; Graves, J.; Linos, N.; Bassett, M.T. Structural racism and health inequities in the USA: Evidence and interventions. Lancet 2017, 389, 1453-1463. [CrossRef]

34. Reskin, B. The Race Discrimination System. Annu. Rev. Sociol. 2012, 38, 17-35. [CrossRef]

35. Rank, M.R.; Hirschl, T.A. The Economic Risk of Childhood in America: Estimating the Probability of Poverty across the Formative Years. J. Marriage Fam. 1999, 61, 1058-1067. [CrossRef]

36. Rothman, J. Multi Modes of Intervention at the Macro Level. J. Community Pract. 2007, 15, 11-40. [CrossRef]

37. Kimbrough-Melton, R.J.; Melton, G.B. Someone will notice, and someone will care: How to build strong com-munities for children. Child Abus. Negl. 2015, 41, 67-78. [CrossRef] [PubMed]

38. Salazar, A.M.; Haggerty, K.P.; Briney, J.S.; Vann, T.; Vinson, J.; Lansing, M.; Catalano, R.F.; Pecora, P.J.; de Haan, B. Assessing an Adapted Approach to Communities That Care for Child Maltreatment Prevention. J. Soc. Soc. Work Res. 2019, 10, 349-369. [CrossRef]

39. Jones-Harden, B.; Simons, C.; Johnson-Motoyama, M.; Barth, R. The Child Maltreatment Prevention Landscape: Where Are We Now, and Where Should We Go? Ann. Am. Acad. Polit. Soc. Sci. 2020, 692, 97-118. [CrossRef]

40. Herrenkohl, T.I.; Leeb, R.T.; Higgins, D. The Public Health Model of Child Maltreatment Prevention. Trauma Violence Abus. 2016, 17, 363-365. [CrossRef]

41. Klevens, J.; Alexander, S. Essentials for Childhood: Planting the Seeds for a Public Health Approach to Preventing Child Maltreatment. Int. J. Child Maltreatment Res. Policy Pract. 2019, 1, 121-132. [CrossRef] 
42. Bosk, E.A.; Van Alst, D.; Van Scoyoc, A. A chronic problem: Competing paradigms for substance abuse in child welfare policy and practice and the need for new approaches. Br. J. Soc. Work. 2017, 47, 1669-1685. [CrossRef]

43. Farrell, A.F.; Britner, P.A.; Kull, M.A.; Struzinski, D.L.; Somaroo-Rodriguez, S.K.; Parr, K.; Westberg, L.; Cronin, B.; Humphrey, C. Final Report: Connecticut's Intensive Supportive Housing for Families Program; Chapin Hall at the University of Chicago: Chicago, IL, USA, 2018 